\title{
Effect of Stachyose on Growth, Non-Specific Immune Response, and Disease Resistance in Oreochromis Niloticus
}

preetham elumalai ( $\square$ epreeth@gmail.com )

Kerala University of Fisheries and Ocean Studies https://orcid.org/0000-0002-9689-9502

Sreeja Lakshmi

Kerala University of Fisheries and Ocean Studies Faculty of Ocean Science and Technology

Ambili Balakrishnan

Kerala University of Fisheries and Ocean Studies Faculty of Ocean Science and Technology

Jesu Arokiaraj

SRM-RI: SRM Research Institute Kattankulathur

Vasaheeran Baskerlingam

Alagappa University Faculty of Science

\section{Einar Ringo}

UiT The Arctic University of Norway University Library: UiT Norges arktiske universitet

Universitetsbiblioteket

\section{Research Article}

Keywords: Disease resistance, Growth, Immune response, Nile tilapia, Stachyose

Posted Date: May 17th, 2021

DOl: https://doi.org/10.21203/rs.3.rs-513048/v1

License: (c) (i) This work is licensed under a Creative Commons Attribution 4.0 International License.

Read Full License 


\section{Abstract}

The study was conducted to investigate the effects of stachyose on immune responses, gut morphology, growth, and disease resistance in Nile tilapia (Oreochromis niloticus). Fishes were distributed randomly into fifteen $150 \mathrm{~L}$ glass tanks with 20 fish tank $^{-1}$ and fed control $(0 \mathrm{~g} / \mathrm{kg}), 2 \mathrm{~g} / \mathrm{kg}, 4 \mathrm{~g} / \mathrm{kg}, 8 \mathrm{~g} / \mathrm{kg}$, and 16 $\mathrm{g} / \mathrm{kg}$ of stachyose. After eight weeks of experimental feeding, skin mucus and serum innate immune parameters (lysozyme, alternative complement, phagocytosis, peroxidase), and growth performance (weight gain, specific growth rate, feed conversion ratio) were analysed, and disease resistance against Streptococcus agalactiae was also determined. Supplementation of stachyose revealed that serum lysozyme, serum and mucus peroxidase activities, weight gain and disease resistance against Streptococcus agalactiae were significantly $(P \leq 0.05)$ higher compared to control fed fish. In contrast, specific growth ratio, phagocytic activity and mucus lysozyme did not show significant $(P>0.05)$ differences.

\section{Introduction}

Soya bean meal (SBM) is added to fish diets as a protein source, and contains a high proportion of indigestible carbohydrates such as polysaccharides and oligosaccharides. Stachyose is an oligosaccharide found in soybean and SBM at high concentration, and is an a- galactooligosaccharide containing $\alpha-(1,6)$ linked galactose molecules bound terminally to sucrose. Animals can not digest galactooligosaccharides due to the absence of the enzyme a- galactosidases, but is fermented by beneficial bacteria. (Mul and Perry. 1994, Choct et al. 2010). Previously, stachyose was considered as an anti-nutritional factor (ANF) due to its negative impact on growth and feed intake (Cai et al. 2012, Choct et al. 2010), but recently stachyose is suggested as a potential prebiotic in food industry due to its beneficial properties (Pacifici et al. 2017, Li et al. 2017)

Prebiotics have gained considerable attention in recent years as alternatives for chemotherapeutic agents in aquaculture practices for stimulating the growth and activity of gut microbiome which in turn improves the host health (Gibson and Roberfroid. 1995). In aquaculture, supplementation of prebiotics ameliorate growth, feed efficiency, immune response, survival rate, disease resistance and modulation of gastrointestinal (GI) microorganisms (e.g. Ring $\varnothing$ et al. 2010, 2014; Ring $\varnothing$ and Song, 2016; Amenyogbe et al. 2020; Hasan and Banerjee. 2020). The mechanism of action of prebiotics involves (1) proliferation of beneficial indigenous bacteria which in turn enhance the production of nutrients such as short chain fatty acids like propionate, butyrate etc (Hoseininfar et al. 2016), (2) increase binding of fatty acids to carbohydrates receptors on immune cells and intestinal epithelial cells, (3) partial absorption of prebiotics from the intestinal tract into the bloodstream making them available for contact with the immune system (Seifert and Watzl, 2007; Cerezuela et al., 2011).

Several studies has investigated the effect of stachyose on intestinal microbiota, gut morphology, bowel and mucosal barrier functions in juvenile turbot (Scophthalmus maximus) and mice (Li et al., 2013, Li et al., 2017, Pacifici et al., 2017, Yang et al., 2018). However, no studies on the effect of stachyose have been 
reported in Nile tilapia (Onchorynchus niloticus). Hence, the present study aims to investigate the effect of stachyose on non specific immune response, disease resistance and growth in Nile tilapia.

\section{Materials And Methods}

\section{Feed preparation}

Five experimental diets were prepared by incorporating dietary stachyose (Xi'an Rongsheng Bio Technology Co., Ltd) to the feed: Diet 1- $0 \mathrm{~g} / \mathrm{kg}$ (Control),, Diet 2- $2 \mathrm{~g} / \mathrm{kg}$, Diet 3- $4 \mathrm{~g} / \mathrm{kg}$, Diet $48 \mathrm{~g} / \mathrm{kg}$, Diet 5 $-16 \mathrm{~g} / \mathrm{kg}$ (Table 1). For the preparation of the pellets, all the ingredients were weighed and thoroughly mixed with oil and water to produce stiff dough. The ingredients were weighed and mixed well with water and oil to make the dough which was made into pellets using a pelletizer. The pellets were dried overnight in an oven at $50^{\circ} \mathrm{C}$ and stored at $4^{\circ} \mathrm{C}$ until use.

\section{Fishes and experimental design}

Nile tilapia (Oreochromis niloticus) were purchased from Chiang Mai Patana Farm, Chiang Mai, Thailand. Fishes were tank acclimatized in $3000 \mathrm{~L}$ tanks for two weeks and fed with control diet. 300 healthy fishes with average weight of $11.25 \pm 0.1 \mathrm{~g}$ were randomly distributed into 15 glass aquariums $(150 \mathrm{~L}$ ) (in triplicates), with 20 fishes in each tank. Fish were fed daily twice until adlibitum. The feeding trial lasted for eight weeks. The water was changed upto $50 \%$ daily to maintain water quality.

\section{Growth performance}

Fishes were weighed after the feeding trial. Weight gain, feed conversion ratio (FCR), specific growth rate (SGR), and survival rate of the fishes were calculated. Weight gain = Final weight (g) - Initial weight (g) / Initial Weight $\times 100, S G R=I_{n}$ final weight $-I_{n}$ initial weight $/$ Days on trial $\times 100, F C R=$ Dry weight of feed consumed $(\mathrm{g})$ / Increase in wet weight of fish (g), SR (\%) = Final fish number / initial fish number $\times 100$

\section{Sample preparation and immunological analysis}

\section{Sample collection}

After eight weeks of feeding, four fishes were randomly caught for immune response analysis. Skin mucus was collected as described by Ross et al. (2000) and Zou et al. (2016). Briefly, two fishes from each tank were anaesthesized using clove oil and placed in individual polythene bags containing $10 \mathrm{ml}$ $\mathrm{Nacl}(50 \mathrm{mM})$. The fishes were gently rubbed for 1-2 $\mathrm{min}$ and the mucus collected was transferred to sterile centrifuge tubes. The samples were centrifuged at $1500 \times \mathrm{g}$ at $4^{0} \mathrm{C}$ for $10 \mathrm{~min}$ and stored at $-80^{0} \mathrm{C}$ until use.

For serum analysis, the blood was collected from the caudal vein with a $1 \mathrm{ml}$ syringe and transferred into a micro centrifuge tube without anticoagulant. It was allowed to clot at $4^{0} \mathrm{C}$ for 4 hours. The serum was separated by centrifugation at $1.500 \times \mathrm{g}$ for $5 \mathrm{~min}$ at $4^{0} \mathrm{C}$ and stored at $-20^{0} \mathrm{C}$ until further use. 
Blood leukocytes were separated according to Chung and Secombes (1988). Briefly, $1 \mathrm{~mL}$ of blood was diluted with 2ml of RPMI 1640 (Roswell Park Memorial Institute 1640) (Gibthai) and mixed with $3 \mathrm{ml}$ of Histopaque (Sigma) taken in a $15 \mathrm{ml}$ tube, centrifuged at $400 \mathrm{xg}$ for $30 \mathrm{~min}$ at room temperature. A white buffy coat of leukocytes cells was observed floating on the top of the Histopaque. Opaque interfaces were carefully transferred to $15 \mathrm{ml}$ tube and mixed with phosphate buffer solution (PBS, pH 7.4) to make a total $6 \mathrm{ml}$ and centrifuged at $250 \mathrm{xg}$ for $10 \mathrm{~min}$. The residue was washed 3 times. The isolated leukocytes was resuspended in PBS and adjusted to the required cell numbers for phagocytosis.

\section{Phagocytic activity}

Phagocytic activity was measured as described previously by Yoshida and Kitao (1991) with some modifications. Briefly, the numbers of leucocytes was adjusted to $2 \times 10^{6}$ cells $\mathrm{mL}^{-1}$, I and added to coverslip and incubated for $2 \mathrm{hrs}$. Un-adhered cells were removed by RPMI 1640 medium. $0.2 \mathrm{ml}$ of latex particles L4530 (Sigma-Aldrich) $\left(2 \times 10^{7}\right.$ particles $\left.\mathrm{ml}^{-1}\right)$ was added to the coverslip and incubated for 2 hrs at $20^{\circ} \mathrm{C}$. The coverslips was washed with the medium, and fixed with differential quick staining. The coverslip was observed under the microscope (Leica) and the number of phagocytosed cells per 300 cells was counted. Phagocytic activity was determined by:

Phagocytic activity $=$ Number of phagocytizing cells/ Number of total cells X 100 .

\section{Lysozyme activity}

Lysozyme activity was measured as described by Parry et al. (1965). Briefly, $25 \mu \mathrm{L}$ of mucus and serum were added into 96-well plate in triplicate. $175 \mu \mathrm{L}$ of Micrococcus lysodeikticus (Sigma Aldrich - USA) suspension $\left(0.3 \mathrm{mg} \mathrm{mL}^{-1}\right.$ in $0.1 \mathrm{M}$ citrate phosphate buffer, $\left.\mathrm{pH} 5.8\right)$ was added to each well. After thorough mixing, change in turbidity was analyzed at $540 \mathrm{~nm}$ at an interval of 30 seconds for 5 min maintaining the temperature at $25^{\circ} \mathrm{C}$ using a micro-plate reader. The equivalent unit of activity of the sample was determined as $\mu \mathrm{g} \mathrm{mL}^{-1}$ serum and compared with the standard. The serum lysozyme activity was measured and expressed in $\mu \mathrm{g} \mathrm{mL}^{-1}$.

\section{Respiratory burst assay}

Respiratory burst activity of phagocytes was estimated by nitrobluetetrazolium reduction as described by Secombes (1990) with slight modifications. Briefly, $175 \mu \mathrm{l}$ of leucocytes $\left(6 \times 10^{6}\right.$ cells / $\left.\mathrm{ml}\right)$ and $25 \mu \mathrm{l}$ of NBT $(1 \mathrm{mg} / \mathrm{ml})$ were added to 96 well plate in triplicate, and incubated for $2 \mathrm{hr}$ at $25^{\circ} \mathrm{C}$. The supernatant was removed and $125 \mu \mathrm{l} 100 \%$ methanol was added. The plate was then incubated at room temperature for $5 \mathrm{~min}$. The wells were washed with 70\% methanol and allowed to air dry. After drying, $125 \mu \mathrm{l} 2 \mathrm{~N}$ potassium hydroxide $(\mathrm{KOH})$ and $150 \mu$ dimethyl sulphoxide (DMSO) was added. The OD was measured at $655 \mathrm{~nm}$ in a microplate reader against blank (KOH and DMSO)

\section{Alternative complement activity (ACH50)}


ACH50 activity of serum and mucus was determined according to Yano (1992). Briefly, rabbit RBC

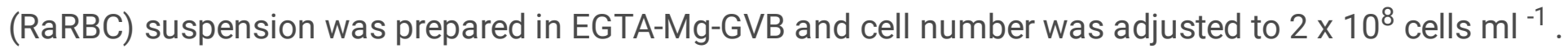
Serum and mucus were serially diluted (0.1- $0.25 \mathrm{ml})$ in EGTA- Mg- GVB in test tubes. RaRBC suspension was added and the tubes were incubated at $20^{\circ} \mathrm{C}$ for 90 min with shaking at intervals. For blank, the same protocol was followed except that the sample was not added and for total lysis tube, $0.1 \mathrm{ml}$ of RaRBC suspension was added to $3.4 \mathrm{ml}$ of distilled water. $3.15 \mathrm{ml}$ of ice cold saline was added to the tubes and centrifuged for $5 \mathrm{~min}, 1600 \mathrm{xg}$ at $4^{0} \mathrm{C}$. The absorbance was measured at $414 \mathrm{~nm}$. The amount of serum with $50 \%$ haemolysis was detected and value was expressed in units $\mathrm{ml}^{-1}$.

\section{Peroxidase assay}

Peroxidase activity was measured according to Quade and Roth (1997) and Cordero et al. (2016). Briefly, $5 \mu \mathrm{l}$ of serum or mucus were added to 96 well ELISA plates. Afterwards, $45 \mu \mathrm{l}$ of Hank's balanced salt solution (HBSS) and $100 \mu \mathrm{l}$ of solution containing $40 \mathrm{ml}$ distilled water, $10 \mu \mathrm{l}$ of $\mathrm{H}_{2} \mathrm{O}_{2}$ and one tablet of 3 , 3', 5, 5' - tetramethylbenzidine (TMB) were added. Subsequently, the reaction was stopped by adding $50 \mu \mathrm{l}$ of $\mathrm{H}_{2} \mathrm{SO}_{4}$. The $\mathrm{OD}$ was measured at $450 \mathrm{~nm}$ against blank. One unit of peroxidase activity was defined as the amount that produces an absorbance change of 1 . It is expressed in units $\mathrm{mg}^{-1}$. The experiment was performed in triplicate.

\section{Disease resistance}

At the end of the feeding trial, nine fish from each aquarium were randomly sampled for testing. The fish were intraperitoneally injected with $0.1 \mathrm{ml}$ of Streptococcus agalactiae in $0.85 \%$ saline $\left(10^{7} \mathrm{CFU} \mathrm{ml}{ }^{-1}\right)$. Dead fish were counted and removed daily. After 15 days, relative percent survival was calculated as follows.

Relative percent survival $(\%)=100$ - (Percentage of mortality in treated group / Percentage of mortality in control group) $\times 100$

\section{Statistical analysis}

The experiments were performed in triplicate $(n=3)$ and the data are represented as mean \pm SD. The data obtained were analysed by Duncans multiple range test using SAS computer program. The results were considered to be significant when $\mathrm{P} \leq 0.05$.

\section{Results}

\section{Growth performance}

The growth performance in Nile tilapia fed with different concentrations of stachyose is shown in Table 2. Although weight gain was significantly $(P \leq 0.05)$ improved in the group fed with $16 \mathrm{~g} \mathrm{~kg}^{-1}$ stachyose, 
no significant $(P>0.05)$ differences were observed in SGR. Lowest FCR value was revealed in control fed fish.

\section{Immune parameters}

Serum and mucus immune responses in Nile tilapia fed Diet 1- $0 \mathrm{~g} / \mathrm{kg}$ (Control), Diet 2- $2 \mathrm{~g} / \mathrm{kg}$, Diet 3- 4 $\mathrm{g} / \mathrm{kg}$, Diet $48 \mathrm{~g} / \mathrm{kg}$, Diet $5-16 \mathrm{~g} / \mathrm{kg}$ are shown in Fig. 1-4. Significant $(P \leq 0.05)$ ameliorate serum lysozyme activity was revealed in the treatment groups when compared to the control group and the fishes fed with Diet $2 \mathrm{~g}$ showed the highest activity (Fig 1$)$. No significant $(P>0.05)$ difference in serum lysozyme activity was observed by feeding fish Diet 4 . Mucus lysozyme activity revealed no significant difference between the treatment groups (Fig 2), while peroxidase activity in serum and mucus showed significant $(P \leq 0.05)$ increase in fish fed Diet 3 , Diet 4 and Diet 5 , with highest activity in dietary group 5 (Fig 3-4). Although the phagocytic activity revealed an increased trend $(P \leq 0.05)$, with highest activity for Diet 3 (Fig. 5).

\section{Disease resistance}

Calculated survival rates of Nile tilapa, 15 days after injection of $S$. agalactiae are shown in Fig. 6 , and the results revealed enhanced resistance by stachyose administration. The relative percent survival rates post challenge was highest in the $16 \mathrm{~g} / \mathrm{kg}$ fed group (96.3\%) followed by $8 \mathrm{~g} / \mathrm{kg}(88.89 \%), 4 \mathrm{~g} / \mathrm{kg}(81.48 \%)$, and $2 \mathrm{~g} / \mathrm{kg}(77.78 \%)$, and the lowest survival rate was revealed in the control group (70.37\%).

\section{Discussion}

Plant based ingredients are a cost effective substitute of fish meal in aquaculture (Olsen and Hasan, 2012; Naylor et al., 2009). Stachyose is an oligosaccharide generally considered to be an anti-nutritional factor (ANF) due to its role in minimizing growth and feeding efficiency in animals if ingested in high levels (Choct et al., 2010). However, several studies suggested thet stachyose is a potential prebiotic candidate which enhance the proliferation of beneficial gut bacteria and promoting intestinal health (Mussatto and Mancilha, 2007; Li et al., 2013; Li, et al., 2017; Pacifici et al., 2017).

The present study showed increase in weight gain in stachyose fed group, but the highest weight gain was observed in the $16 \mathrm{~g} / \mathrm{kg}$ fed group. These results are in contrast to Cai et al. (2012) where stachyose and raffinose reported minor role in soybean induced growth retardation in silver crucian carp (Carassius auratus gibelio). In avian models, Jiang et al. (2006) observed depressed body weight in broiler chickens fed with stachyose. In accordance to the present study, administration of moderate levels of stachyose for a period of 12 weeks resulted in significant increase in the growth, digestive enzyme activity and improved gut morphology in juvenile turbot (Hu et al., 2015). Sorensen et al. (2011) reported that administration of stachyose did not revealed negative effects on protein or fat digestibility and the intestinal structure in Atlantic salmon (Salmo salarL.). These effects may be due to the association of the oligosaccharide to other ANFs present in the SBM (Hu et al., 2015). The conflicting result in various studies may be due to that certain factors such as duration of experiment, dietary administration levels of 
stachyose, model organism, diet, rearing environment and tolerance of ANFs (Choct et al., 2010, Sorensen et al., 2011).

Elevation of immune response in fishes by administration of prebiotics is important in aquaculture (Ahmadi et al., 2014; Sohn et al., 2000). The present study is the first one to evaluate the role of stachyose on various mucus and serum immune response in Nile tilapia, and revealed a significant increase in the mucus and serum immune parameters, disease resistance in stachyose fed fish. Serum lysozyme activity significantly increased in fish fed $2 \mathrm{~g} / \mathrm{kg}$ of stachyose. Lysozyme is an important parameter ofthe nonspecific immune response (Saurabh and Sahoo, 2008). In accordance with the results of the present study, Xu et al. (2017) evaluated the effect of raffinose (a group of oligosaccharides in soya beans), and reported that myeloperoxidase and respiratory burst (NBT) activities were significantly higher in hybrid sturgeon (Acipenser baerii Brandt $\triangle \times A$. schrenckii Brandt $\triangle$ ) fed raffinose supplemented diets. In contrast, Wang et al. (2016) observed that lysozyme activity significantly decreased in juvenile turbot fed $60 \%$ SBM. Likewise, in the present study, the mucus, seum peroxidase and phagocytic activities were significantly improved by stachyose administration.

Oligosaccharides improve the non-specific immune response by (1) proliferation of lactic acid bacteria which inhibits the growth of pathogenic microbes and (2) enhancing the immunoglobulin levels, lysozyme activity, complements and reactive oxygen species (ROS) which are detrimental to the fish pathogens (Hoseinifar et al., 2016; Dasbet al., 2009; Meng et al., 2017; Dawood et al., 2016). The increase in survival evealed in the present study may be due to enhancement of innate immune parameters in Nile tilapia or alteration of the beneficial intestinal microbiota which enhances gut health. Ma et al. (2017) demonstrated that high dose of stachyose caused an increase in bifidobacterium and lactic acid bacteria resulting in significant enhancement in immunological parameter. However, this is an preliminary study and identification of exact mechanism of action need further studies.

\section{Conclusion}

The present study reveals the potential use of stachyose a dietary supplement. The eight weeks growth trial showed an significant increase in weight gain and innate immune parameters, and disease resistance against $S$. agalactiae. However, further information is needed on the effect of stachyose on digestive enzyme activities, gut microbiota, gut histology and metabolisms.

\section{Declarations}

\section{Acknowledgements}

The authors thank the Kerala University of Fisheries and Ocean Studies, Panangad, Kochi, Kerala for providing the financial assistance.

\section{Author contributions}


Elumalai Preetham: Conceptualisation, execution of this project, acquisition and interpretation of experimental datas and drafting the manuscript. Sreeja Lakshmi: Writing- review \& editing. Ambily Balakrishnan: Conducting experiments. Jesu Arockiaraj \& Baskaralingam Vaseeharan: Conceptualisation and data curation. Einar Ringø: Writing - review \& editing. All authors read and approved the final manuscript.

Funding Not applicable

Data availability All data generated and analysed during this study are included for publication.

\section{Ethics statement}

All experiments were performed in compliance with the guidelines for animal welfare and the use of animals as prescribed by the Institutional Animal Ethics Committee (SOST/PhD003/2019) of Kerala University of Fisheries and Ocean Studies, Kochi, Kerala, India.

\section{Conflic of interest}

The authors declare that they have no conflict of interest.

Consent to participate All authors participated in this research.

Consent for publication All authors read and approved the final manuscript.

Code availability Not applicable

\section{References}

1. Mul AJ , Perry FG (1994) The role of fructo-oligosaccharides in animal nutrition. In: Recent Advances in Animal Nutrition. Garnsworthy PC., and Cole DJA (Eds)., Nottingham University Press, Nottingham. 57-79.

2. Das BK, Pradhan J, Sahu S (2009) The effect of Euglena viridis on immune response of uohu, Labeo rohita (Ham.). Fish Shellfish Immunol 26:871-876.

3. Secombes CJ (1990) Isolation of salmonid macrophage and analysis of their killing ability in: Stolen JS, F.T., Anderson DP, Roberson BS, Van WB, W inkel M (Ed.), Techniques in fish immunology, SOS Publication, New Jersey 137-152.

4. Cai CF, WWang WJ, Ye YT, Krogdahl A, Wang YL, Xia YM, Yang CG (2012) Effect of soybean meal, raffinose and stachyose on the growth, body composition, intestinal morphology and intestinal microflora of juvenile allogynogenetic silver crucian carp (Carassius auratus gibelio $₫ \times$ Cyprinus carpio[).Aquac Res 43:128-

5. Ring $\varnothing$ E, Song SK (2016) Application of dietary supplements (synbiotics and probiotics in combination with plant products and $\beta$ - glucans) in aquaculture. Aquacult Nutr 22:4-24. 
6. Amenyogbe E, Chen G, Wang Z, Huang J, Huang B, Li H (2020) The exploitation of probiotics, prebiotics and synbiotics in aquaculture: present study, limitations and future directions. : a review. Aquacult Int 28:1017-1041.

7. Gibson GR, Roberfroid MB (1995) Dietary modulation of the human colonic microbiota. J Nutr 125:1401-12

8. Cordero H, Cuesta A, Meseguer J, Esteban MA (2016) Changes in the levels of humoral immune activities after storage of gilthead seabream (Sparus aurata) skin mucus. Fish Shellfish Immunol 58:500-507.

9. Hu H, Zhang Y, Mai K, Ai Q, Xu W, Zhang W, Li Y, Liu J (2015) Effects of dietary stachyose on growth performance, digestive enzyme activities and intestinal morphology of juvenile turbot (Scophthalmus maximus). J Ocean Univ China 14:905-912.

10. Khodadadian Zou H, Hoseinifar SH, KolangiMiandare H, Hajimoradloo A (2016) Agaricusbisporus powder improved cutaneous mucosal and serum immune parameters and up-regulated intestinal cytokines gene expression in common carp (Cyprinus carpio) fingerlings. Fish Shellfish Immunol 58:380-

11. Jiang HQ, L. Gong M, Ma YX, He YH, Li DF, Zhai HX (2006). Effect of stachyose supplementation on growth performance, nutrient digestibility and caecalfermen- tation characteristics in broilers. $\mathrm{Br}$ Poult Sci 47:516-522.

12. Sohn K, Kim M, Kim J, Han IK (2000) The role of immunostimulants in nonogastric animal and fishreview. Asian- Australasian J Animal Sci 13:1178-87.

13. Hasan KN, Banerjee G (2020) Recent studies on probiotics as beneficial mediator in aquaculture: a review. JoBAZ81:53

14. Wang L, Zhoua H, He R, Xu W, Mai K, He G (2016) Effects of soybean meal fermentation by Lactobacillus plantarumP8 on growth, immune responses, and intestinal morphology in juvenile turbot (Scophthalmus maximus). Aquaculture 464:87-94.

15. Choct M, Dersjant-Li Y, McLeish J, Peisker M (2020) Soy oligosaccharides and soluble non-starch polysaccharides: A review of digestion, nutritive and anti-nutritive effects in pigs and poultry. AsianAustralas J Anim Sci 23:1386-1398.

16. Quade MJ, Roth, JA (1997) A rapid, direct assay to measure degranulation of bovine neutrophil primary granules. Vet Immunol Immunopathol 58:239-248.

17. Dawood MAO, Koshio S (2016) Recent advances in the role of probiotics and prebiotics in carp aquaculture: a review. Aquaculture 454:243-251.

18. Sørensen M, Penn M, El-Mowafi A, Storebakken T, Chunfang C, Øverland M, Krogdahl A (2011) Effect of stachyose, raffinose and soya-saponins supplementation on nutrient digestibility, digestive enzymes, gut morphology and growth performance in Atlantic salmon (Salmo salar, L). Aquaculture 314:145-152.

19. Ross NW, Firth KJ, Wang A, Burka JF, Johnson SC (2000) Changes in hydrolytic enzyme activities of naive Atlantic salmon Salmo salar skin mucus due to infection with the salmon louse 
Lepeophtheirussalmonis and cortisol implantation. Dis Aquat Org 41:43-

20. Ahmadi PY, Farahmand H, Miandare HM, Mirvaghefi A, Hoseinifar SH (2014) The effects of dietary Immunogen ${ }^{\circledR}$ on innate immune response, immune related genes expression and disease resistance of rainbow trout (Oncorhynchus mykiss). Fish Shellfish Immunol. 37:209-214.

21. Yang P, Hu H, Liu Y, Li Y, Ai Q, Xu W, Zhang W, Zhang Y, Zhang Y, Mai K (2018) Dietary stachyose altered the intestinal microbiota profile and improved the intestinal mucosal barrier function of juvenile turbot, Scophthalmus maximus L. Aquaculture 486:98-106

22. Cerezuela R, Meseguer J, Esteban MA (2011) Current knowledge in synbiotic use for fish aquaculture: A review. J Aquac Res Development S1:008. doi:10.4172/2155-9546.S1-008

23. Naylor RL, Hardy RW, Bureau DP, Chiu A, Elliott M, Farrell AP, Forster I, Gatlin DM, Goldburg RJ, Hua K, Nichols PD (2009) Feeding aquaculture in an era of finite resources. Proceedings of the National Academy of Sciences 106: 15103-15110.

24. Olsen RL, Hasan MR (2012) A limited supply of fish meal: Impact on future increases in global aquaculture production. Trend Food Sci Technol 27: 120- 128.

25. Parry RM, Chandan RC, Shahani KM (1965) A rapid and sensitive assay of muramidase. Exp Biol Med 119:384-386.

26. Saurabh S, Sahoo P (2008) Lysozyme: an important defence molecule of fish innate immune system. Aquacult Res 39: 223-39.

27. Chung S, Secombes CJ (1998) Analysis of events occurring within teleost macrophages during the respiratory burst. Comp Biochem Physiol Part B: 89:539-544.

28. Pacifici S, Song J, Zhang C, Wang Q, Glahn RP, Kolba N, Tako E (2017) Intra amniotic administration of raffinose and stachyose affects the intestinal brush border functionality and alters gut microflora populations. Nutrients 9. doi: 10.3390/nu9030304.

29. Seifert S, Watzl B (2007) Inulin and Oligofructose: Review of experimental data on immune modulation. J Nutr 137:2563S-2567S.

30. Hoseinifar SH, Ring $ø$ E, Shenavar Masouleh A, Esteban MA (2016) Probiotic, prebiotic and synbiotic supplements in sturgeon aquaculture: a review. Rev Aquac 8:89-102.

31. Hoseinifar SH, Zoheiri F, Dadar M, Rufchaei R, Ring $\varnothing$ E, Dietary galactooligosaccharide elicits positive effects on non-specific immune parameters and growth performance in Caspian white fish (Rutilus frisiikutum) fry. Fish Shellfish Immunol 56: 467-472.

32. Mussatto SI, Mancilha IM (2007) Non-digestible oligosaccharides: a review. Carbohydr Polym 68.:587-597.

33. Li T, Lu X, Yang X (2013) Stachyose-enriched a-galacto-oligosaccharides regulate gut microbiota and relieve constipation in mice. J Agric Food Chem 61:11825-

34. Yano T (1992) Assays of hemolitic complement activity. in: Stolen, J.S., Fletcher, T.C., Anderson, D.P., Kaatari, S.L., Roley, A.F. (Eds.), Techniques in Fish Immunology. SOS Publications, Fair Haven, NJ. $131-141$. 
35. Yoshida T, Kitao T (1991) The opsonic effect of specific immune serum on the phagocytic and chemiluminescent response in rainbow trout, Oncorhynchus mykiss Fish Pathol 26:29-33.

36. Meng X, Wang JT, Wan WJ, Xu MM, Wang TT (2017) Influence of low molecular weight chitooligosaccharides on growth performance and non-specific immune response in Nile tilapia Oreochromis niloticus, Aquacult Int $25: 1265-1277$.

37. Li Y, Hu H, Liu J, Yang P, Zhang Y, Ai Q, Xu W, Zhang W, Mai K (2017) Dietary soya allergen $\beta$ conglycinin induces intestinal inflammatory reactions, serum-specific antibody response and growth reduction in a carnivorous fish species, turbot Scophthalmus maximus Aquacult Res 48 :4022-4037.

38. Ma Y, Wu X, Giovanni V, Meng X (2017) Effects of soybean oligosaccharides on intestinal microbial communities and immune modulation in mice. Saudi J Biol Sci 24:114-121.

\section{Tables}

Table 1: Formulation and proximate composition of experiment diet (\% dry matter) 


\begin{tabular}{|c|c|c|c|c|c|}
\hline \multirow[t]{2}{*}{ Ingredients } & \multicolumn{5}{|c|}{ Diets $\left(\mathrm{g} \mathrm{kg}^{-1}\right)$} \\
\hline & Diet 1 & Diet 2 & Diet 3 & Diet 4 & Diet 5 \\
\hline Fish meal & 270 & 270 & 270 & 270 & 270 \\
\hline Corn meal & 200 & 200 & 200 & 200 & 200 \\
\hline Soybean meal & 270 & 270 & 270 & 270 & 270 \\
\hline Wheat flour & 60 & 60 & 60 & 60 & 60 \\
\hline Rice bran & 150 & 150 & 150 & 150 & 150 \\
\hline Stachyose & 0 & 2 & 4 & 8 & 16 \\
\hline Cellulose & 30 & 28 & 26 & 22 & 14 \\
\hline Soybean oil & 5 & 5 & 5 & 5 & 5 \\
\hline Premix $^{1}$ & 10 & 10 & 10 & 10 & 10 \\
\hline Vitamin C & 5 & 5 & 5 & 5 & 5 \\
\hline \multicolumn{6}{|c|}{ Proximate composition (\% dry matter basis) } \\
\hline \multicolumn{2}{|l|}{ Dry matter (\%) } & \multicolumn{4}{|c|}{96.73} \\
\hline \multicolumn{2}{|l|}{ Ash (\%) } & \multicolumn{4}{|l|}{0.07} \\
\hline \multicolumn{2}{|l|}{ Fiber (\%) } & \multicolumn{4}{|l|}{0.00} \\
\hline \multicolumn{2}{|l|}{ Energy (cal/g) } & \multicolumn{4}{|l|}{3890} \\
\hline \multicolumn{2}{|l|}{ Crude Protein (\%) } & \multicolumn{4}{|l|}{0.00} \\
\hline \multicolumn{2}{|l|}{ Crude lipid (\%) } & \multicolumn{4}{|l|}{0.16} \\
\hline
\end{tabular}

Table 1. Vitamin and trace mineral mix supplemented as follows $\left(\mathrm{IU} \mathrm{kg}^{-1} \mathrm{or} \mathrm{g} \mathrm{kg}^{-1}\right.$ diet): retinyl acetate 1,085,000 IU; cholecalciferol 217,000 IU; D, L-a-tocopherol acetate $0.5 \mathrm{~g}$; thiamin nitrate $0.5 \mathrm{~g}$; pyridoxine hydrochloride $0.5 \mathrm{~g}$; niacin $3 \mathrm{~g}$; folic $0.05 \mathrm{~g}$; cyanocobalamin $10 \mathrm{~g}$; Ca pantothenate $1 \mathrm{~g} \mathrm{~kg}^{-1}$; inositol $0.5 \mathrm{~g}$; zinc $1 \mathrm{~g}$; copper $0.25 \mathrm{~g}$; manganese $1.32 \mathrm{~g}$; iodine $0.05 \mathrm{~g}$; sodium $7.85 \mathrm{~g}$.

Table 2: Growth performances and feed utilization of the Nile tilapia fed different levels of stachyose 


\begin{tabular}{|lllll|}
\hline Treatment groups & FCR & WG & SGR & Survival rate (\%) \\
(g) & $(\%)$ & \\
\hline Diet 1 & $1.02 \pm 0.02^{\mathrm{c}}$ & $56.80 \pm 1.97^{\mathrm{b}}$ & $4.01 \pm 0.07^{\mathrm{a}}$ & 95 \\
\hline Diet 2 & $1.07 \pm 0.01^{\mathrm{c}}$ & $58.04 \pm 2.12^{\mathrm{b}}$ & $4.07 \pm 0.09^{\mathrm{a}}$ & 95 \\
\hline Diet 3 & $1.02 \pm 0.02^{\mathrm{bc}}$ & $59.61 \pm 0.71^{\mathrm{b}}$ & $4.10 \pm 0.03^{\mathrm{a}}$ & 93.3 \\
\hline Diet 4 & $1.08 \pm 0.01^{\mathrm{b}}$ & $54.50 \pm 0.97^{\mathrm{b}}$ & $3.93 \pm 0.04^{\mathrm{a}}$ & 93.3 \\
\hline Diet 5 & $1.22 \pm 0.01^{\mathrm{a}}$ & $62.03 \pm 1.95^{\mathrm{a}}$ & $4.16 \pm 0.06^{\mathrm{a}}$ & 96.67 \\
\hline
\end{tabular}

Table 2: . Diet 1 (control), Diet $2\left(2 \mathrm{~g} \mathrm{~kg}^{-1}\right)$, Diet $3\left(4 \mathrm{~g} \mathrm{~kg}^{-1}\right)$, Diet $4\left(84 \mathrm{~g} \mathrm{~kg}^{-1}\right)$ and Diet $5\left(16 \mathrm{~g} \mathrm{~kg}^{-1}\right)$. Values are presented as the mean \pm SE.Means in the same row with different superscripts are significantly different $(P<0.05)$.

\section{Figures}

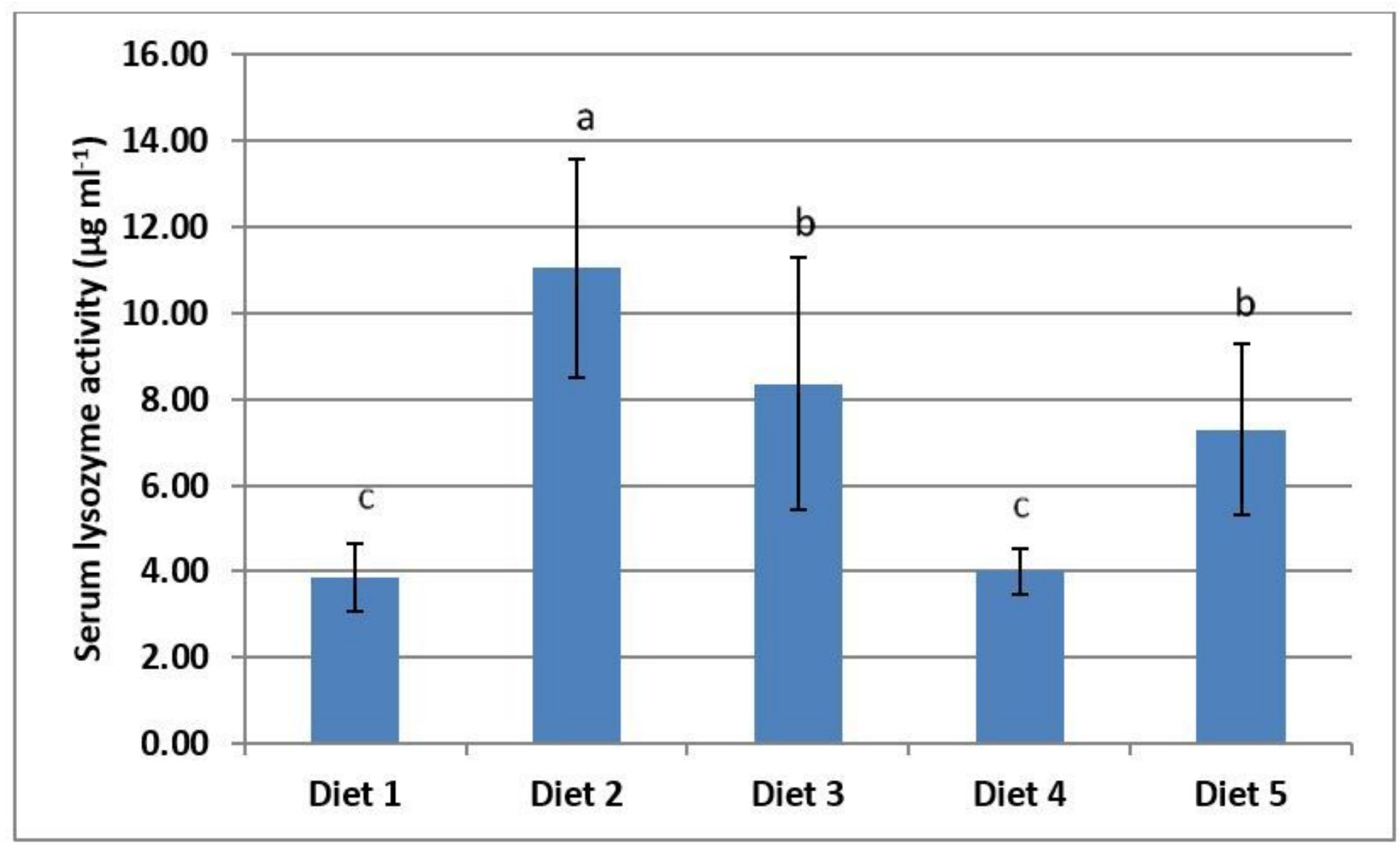

Figure 1 
Serum lysozyme activity of Nile tilapia, O. niloticus fed different diets: Diet 1 (control), Diet 2 ( $2 \mathrm{~g} \mathrm{~kg}-1)$, Diet 3 (4g kg -1), Diet 4 (8 4g kg -1) and Diet 5 (16 g kg -1)(mean \pm S.E.). Columns sharing the same superscript letter are not significantly different $(P<0.05)$.

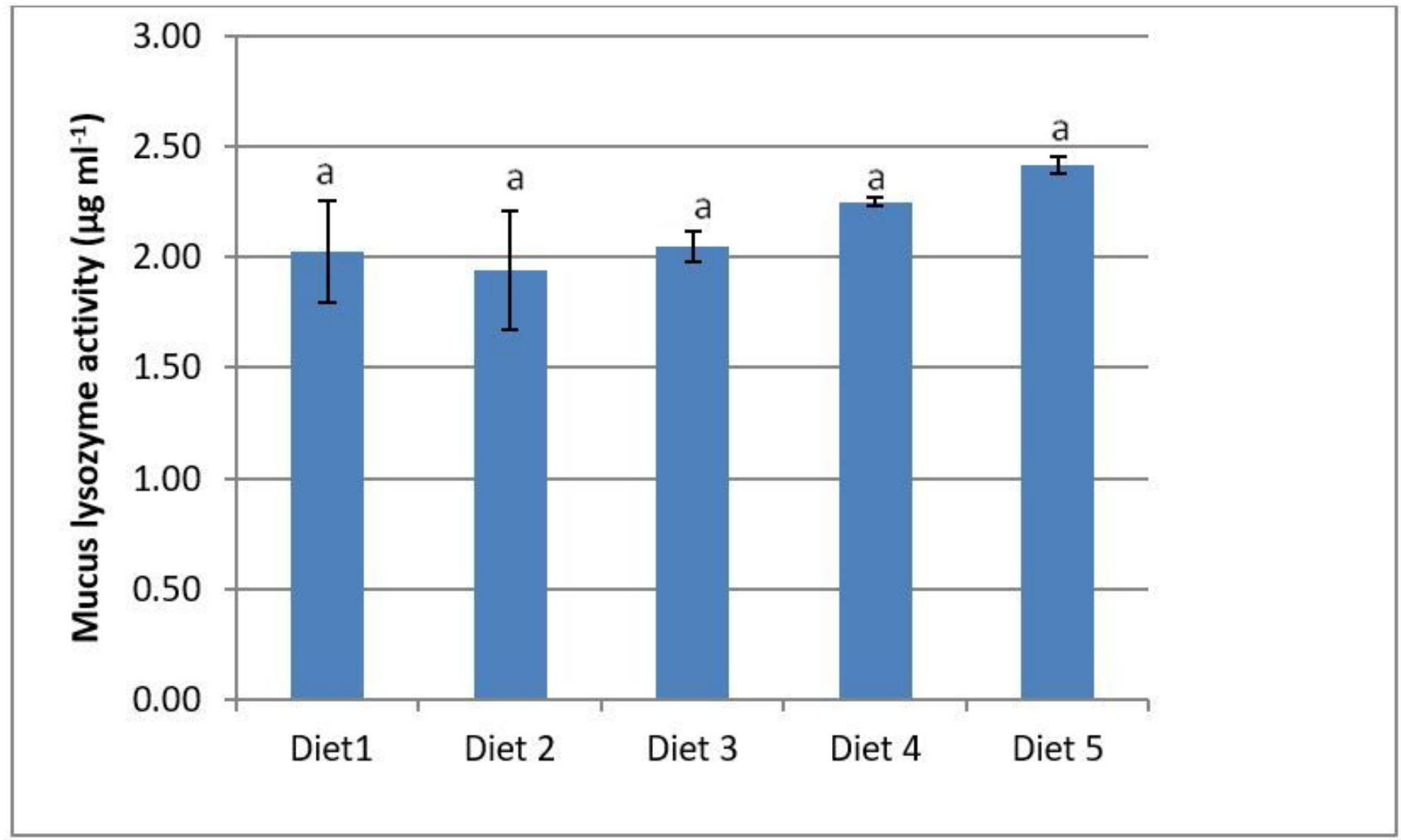

Figure 2

Mucus lysozyme activity of Nile tilapia, O. niloticus fed different diets: Diet 1 (control), Diet 2 (2 g kg-1), Diet 3 (4g kg -1), Diet 4 (8 $4 \mathrm{~g} \mathrm{~kg} \mathrm{-1)} \mathrm{and} \mathrm{Diet} 5$ (16 g kg -1) (mean \pm S.E.). Columns sharing the same superscript letter are not significantly different $(P<0.05)$. 


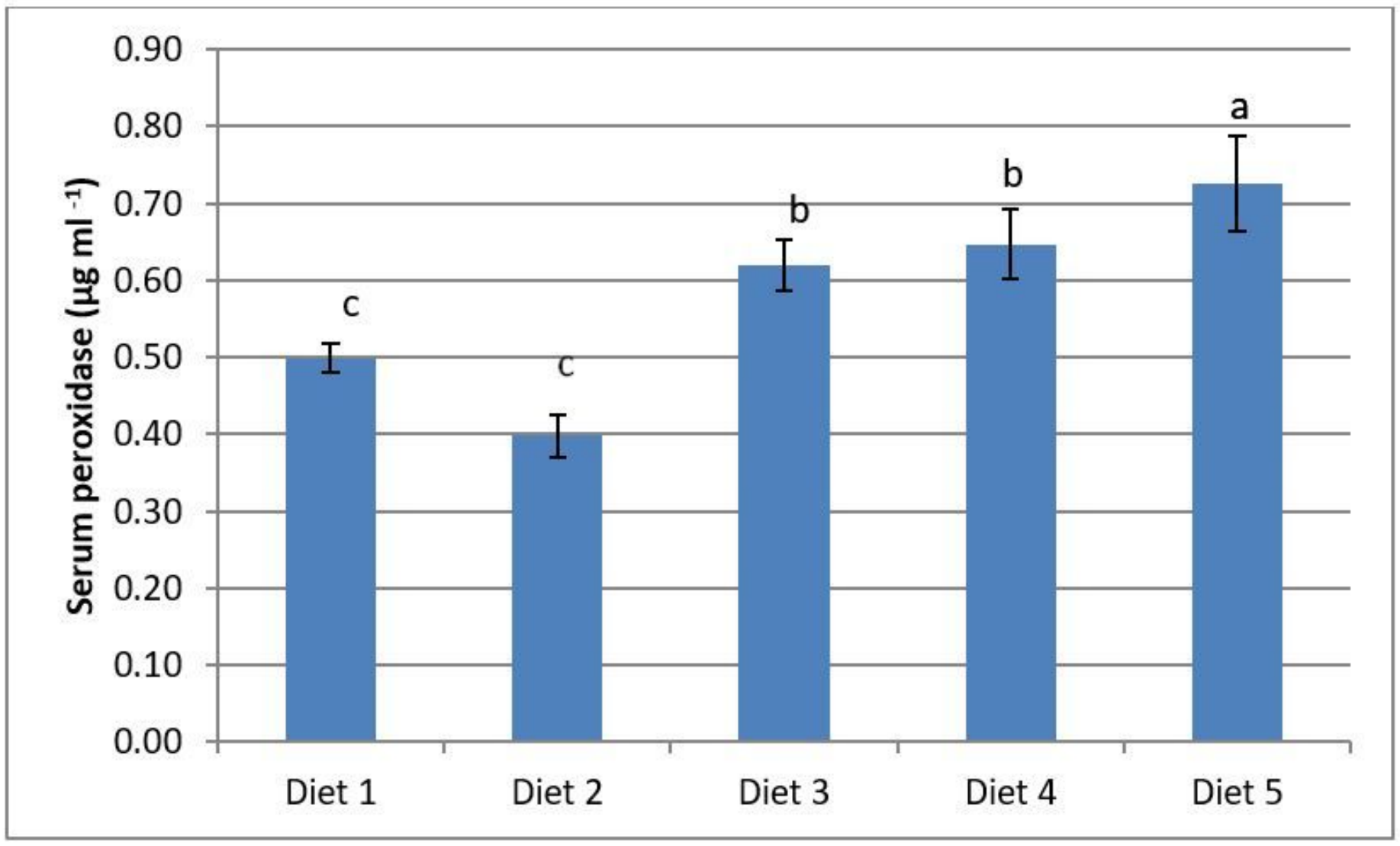

Figure 3

Serum peroxidase activity of Nile tilapia, 0 . niloticus fed different diets: Diet 1 (control), Diet 2 ( $2 \mathrm{~g} \mathrm{~kg}-1)$, Diet 3 (4g kg -1), Diet $4(84 \mathrm{~g} \mathrm{~kg} \mathrm{-1)} \mathrm{and} \mathrm{Diet} 5(16 \mathrm{~g} \mathrm{~kg} \mathrm{-1)(mean} \pm$ S.E.). Columns sharing the same superscript letter are not significantly different $(P<0.05)$. 


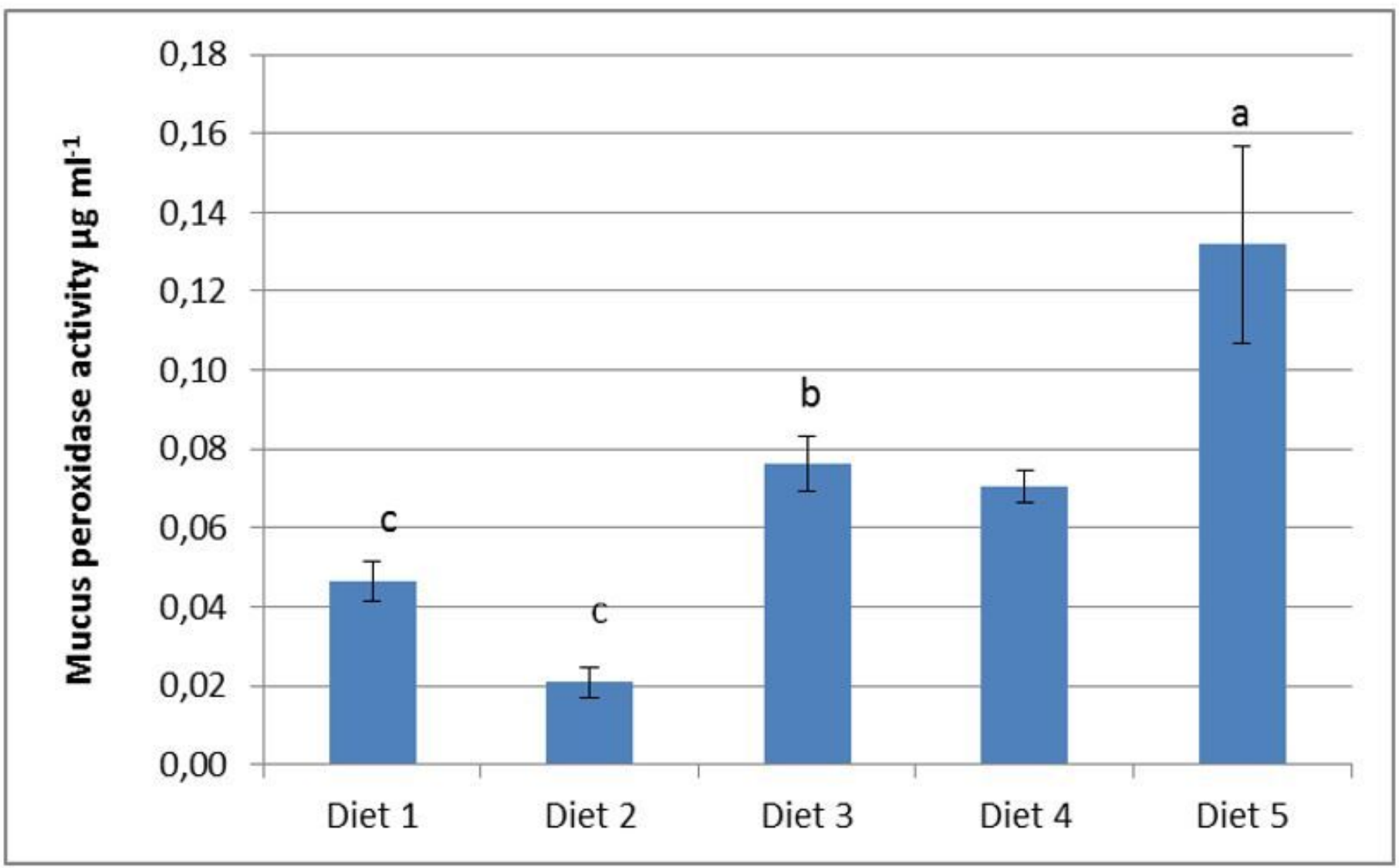

Figure 4

Mucusperoxidase activity of Nile tilapia, O. niloticus fed different diets: Diet 1 (control), Diet 2 (2 g kg-1), Diet 3 (4g kg -1), Diet 4 (8 $4 \mathrm{~g} \mathrm{~kg} \mathrm{-1)} \mathrm{and} \mathrm{Diet} 5$ (16 g kg -1)(mean \pm S.E.). Columns sharing the same superscript letter are not significantly different $(P<0.05)$. 


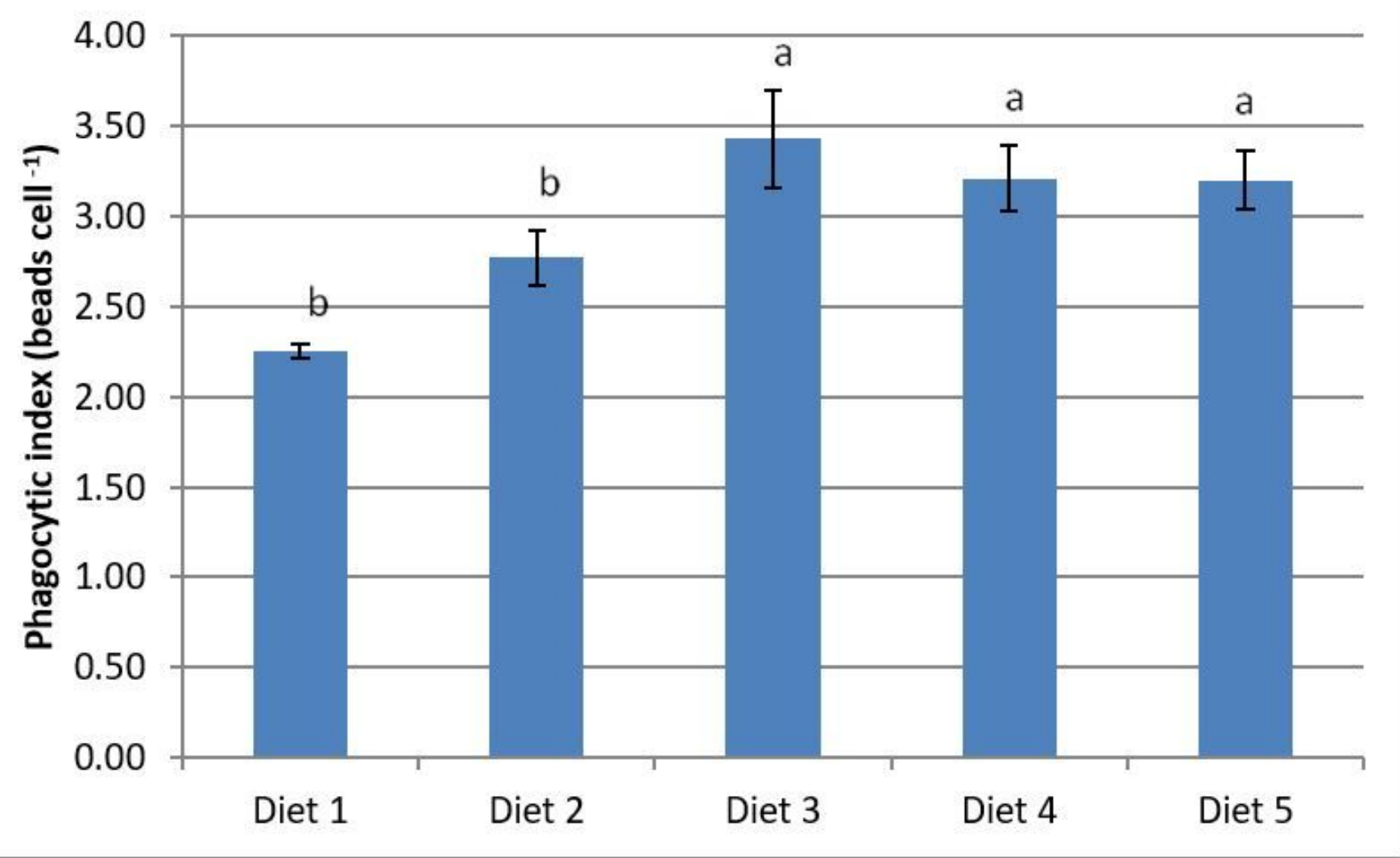

Figure 5

Phagocytic activity of Nile tilapia, 0 . niloticus fed different diets: Diet 1 (control), Diet 2 (2 g kg-1), Diet 3 $(4 \mathrm{~g} \mathrm{~kg}-1)$, Diet $4(8 \mathrm{gg} \mathrm{kg}-1)$ and Diet $5(16 \mathrm{~g} \mathrm{~kg}-1)$ (mean \pm S.E.). Columns sharing the same superscript letter are not significantly different $(P<0.05)$. 


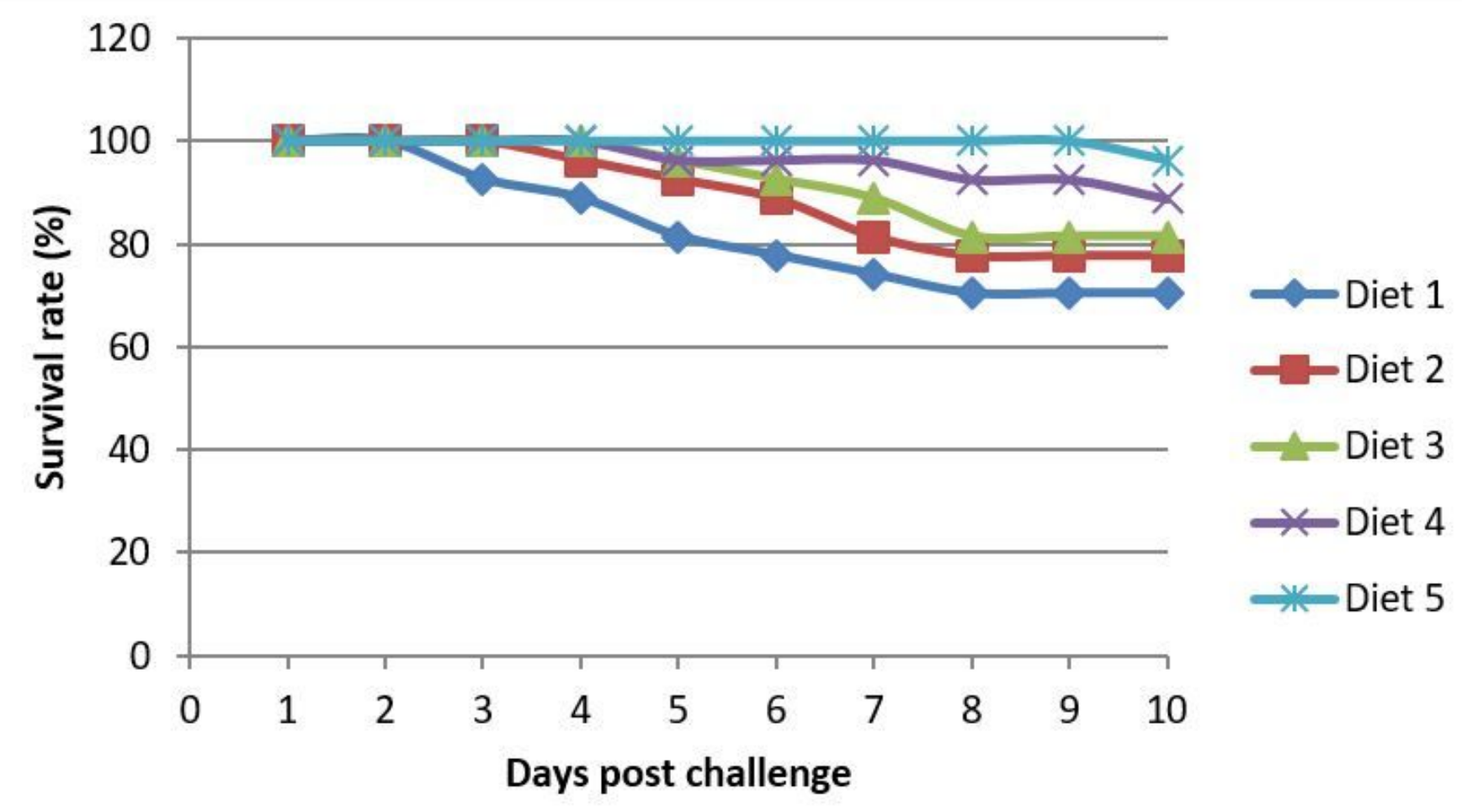

Figure 6

Survival rate of Nile tilapia, O. niloticus fed different diets: Diet 1 (control), Diet 2 (2 g kg-1), Diet 3 (4g kg -1), Diet 4 (8 $4 \mathrm{~g} \mathrm{~kg} \mathrm{-1)}$ and Diet 5 (16 g kg-1)(mean \pm S.E.). 